Available online at https://jurnal.stmikroyal.ac.id/index.php/jurdima

\title{
PEMANFAATAN WEBSITE SEBAGAI MEDIA INFORMASI PADA POLSEK PORSEA KABUPATEN TOBA SAMOSIR
}

\author{
M. Irfan Fahmi*1, Wan Mariatul Kifti ${ }^{1}$, Nasrun Marpaung ${ }^{1}$ \\ ${ }^{1}$ Sistem Informasi, STMIK Royal \\ email: *irfanlona759@gmail.com
}

\begin{abstract}
Use of the website at any institution or institution that uses the right technology as a medium to provide the latest information. Community Service Activities use information technology in the use of websites as information media to provide up-to-date and directly obtained information from police institutions for the community. With the existence of a website on the Porsea police station, it can improve the quality of Porsea police services against the Porsea community in receiving information, news about the Porsea area, and finding progress in increasing the entire Porsea police station that can be directly accessed by the Porsea community. The training method used is the indoor training method using the lecture method, discussion and question and answer and direct practice related to the use of the website. By applying the application in practice, it will increase knowledge about Porsea police in using applications to process and post news, information, and forms of service to Porsea police.
\end{abstract}

Keywords: Website, Media Information, Porsea Sector Police

\begin{abstract}
Abstrak: Penggunaan website pada setiap lembaga maupun instansi merupakan pemanfaatan teknologi yang tepat sebagai media untuk memberikan informasi yang up to date. Kegiatan Pengabdian kepada Masyarakat berupa pelatihan pemanfaatan teknologi informasi dalam penggunaan website sebagai media informasi bertujuan untuk memberikan informasi yang up to date dan langsung diperoleh dari lembaga kepolisian kepada masyarakat. Dengan adanya website pada polsek Porsea tentunya dapat meningkatkan kualitas pelayanan polsek Porsea terhadap masyarakat Porsea dalam menerima informasi, berita seputar daerah Porsea, dan mengetahui perkembangan kinerja seluruh personil polsek Porsea yang dapat langsung dirasakan masyarakat Porsea. Metode pelatihan yang digunakan adalah bentuk pelatihan dalam ruangan dengan menggunakan metode ceramah, diskusi dan tanya jawab serta praktek langsung terkait penggunaan website tersebut. Dengan tahap-tahap penggunakan aplikasi dalam prakteknya akan meningkatkan pengetahuan personil polsek Porsea dalam menggunakan aplikasi untuk mengolah dan posting berita, informasi, maupun bentuk pelayanan pada polsek Porsea.
\end{abstract}

Kata Kunci : Website, Media Informasi, Polsek Porsea 
Available online at https://jurnal.stmikroyal.ac.id/index.php/jurdima

\section{PENDAHULUAN}

Perkembangan teknologi informasi dan komunikasi sangat berkembang dengan pesat yang mempengaruhi gaya pikir dan kemampuan manusia. Setiap pekerjaan tentunya ingin diselesaikan dengan cepat dan tepat serta dengan hasil yang baik. Kemajuan teknologi komputer sebagai pendukung pemrosesan data dan informasi telah menjadi kebutuhan pokok dalam suatu instansi. Instansi jasa pelayanan yang memberikan pelayanan kepada masyarakat, sangat membutuhkan kecepatan pelayanan informasi sehingga dapat memberikan pelayanan yang optimal kepada penggunanya.

Polisi adalah suatu pranata umum sipil yang menjaga ketertiban, keamanan dan penegakan hukum diseluruh wilayah negara.Kepolisian adalah salah satu lembaga penting yang memainkan tugas utama sebagai penjaga keamanan, ketertiban dan penegakan hukum, sehingga lembaga kepolisian pasti lah ada di seluruh negara berdaulat.

Sebagai lembaga yang memberikan keamanan pada masyarakat, tentunya sebuah lembaga sudah seharusnya dapat berinterasksi lebih dekat dengan masyarakat tanpa ada pembatas, untuk mendapatkan keamanan, pelayanan, dan informasi dari layanan kepolisian. Informasi tentang kegiatan kepolisian tentang kepedulian dan kesigapan polisi dalam membantu dan memberikan pelayanan terbaik kepada masyarakat kini dapat dipublikasi di media sebagai bentuk dedikasi yang tinggi terhadap masyarakat oleh kepolisian.

Untuk meningkatkan kualitas pelayanan Polsek Porsea tentunya membutuhkan media informasi seperti website untuk menyediakan informasi yang up to datesebagai bentuk kepedulian dan bentuk kinerja yang baik yang dapat diakses oleh masyarakat Porsea.

Website yang dibuat akan menjadi media atau sistem informasi yang menyampaikan setiap kegiatan, prestasi kerja, serta seluruh jenis pelayanan terhadap masyarakat pada polsek Porsea.

Oleh sebab itu, pemanfaatan teknologi informasi dalam bidang pembuatan website sebagai media informasi akan sangat membantu Polsek Porsea untuk menciptakan kedekatan terhadap masyarakat.

Website (Situs Web) merupakan kumpulan dari halaman-halaman web yang berhubungan dengan file-file lain yang terkait. Dalam sebuah website terdapat suatu halaman yang dikenal dengan sebutan home page. Home page adalah sebuah halaman yang pertama kali dilihat ketika seseorang mengunjungi website. Dari home page, pengujung dapat mengklik hyperlink untuk pindah kehalaman lain yang terdapat dalam website tersebut.(Hendrianto, 2014)

\section{METODE}

Untuk menciptakan kegiatan pelatihan yang berlangsung dengan baik serta dengan pemahaman yang baik, maka dilakukan pelatihan dengan menggunakan metode. Yaitu dengan menggunakan metode demostrasi, praktek, dan penjelasan terhadap sistem atau aplikasi yang akan digunakan. Demonstrasi dilakukan pada tahap awal dengan diperhatikan langsung oleh peserta dalam setiap tahapannya yang diiringi dengan penjelasan fungsi dan kegunaan dari sistem atau aplikasi yang akan digunakan tersebut. Setelah mulai memahami, para peserta mempraktikan langsung penggunaan aplikasi tersebut. 
Available online at https://jurnal.stmikroyal.ac.id/index.php/jurdima

Praktik langsung dilakukan pada komputer yang tersedia pada polsek Porsea dengan materi-materi terkait informasi dari polsek Porsea yang sudah disiapkan. Kegiatan ini dilaksanakan pada hari Jumat sampai dengan Sabtu, pada tanggal 22 sampai dengan 23 Maret 2019, bertempat di Polsek Porsea, Kabupaten Toba Samosir, Sumatera Utara.

\section{PEMBAHASAN}

\section{Aplikasi yang digunakan dalam penggunaan website adalah menggunakan wordpress yang disesuaikan dengan kebutuhan polsek Porsea. \\ Adapun tampilan aplikasi wordpress yang sudah diinstal adalah sebagai berikut}

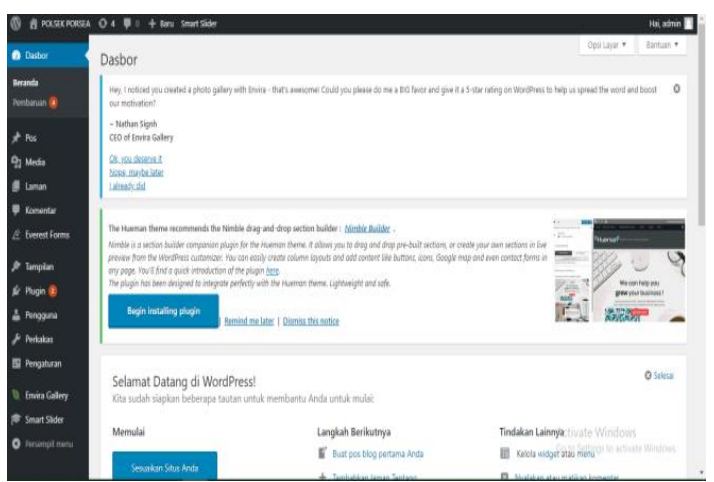

Gambar 1. Halaman Wordpress setelah Instalasi

Materi dalam pelatihan ini dibuat sesuai dengan kebutuhan dalam menyampaikan informasi kegiatan, prestasi kerja, serta layanan kepada masyarakat melalui media informasi website. Bagi staf IT kepolisian yang sudah memiliki keterampilan dalam menggunakan komputer dan manajemen website dalam proses pemberian dan penyampaian informasi yang baik maka menjadi lebih mudah bagi narasumber dalam berbagi pengetahuan dan praktek penggunaannya.

Adapun contoh halaman manajemen admin website polsek Porsea dalam pelatihan dapat dilihat pada gambar di bawah ini:

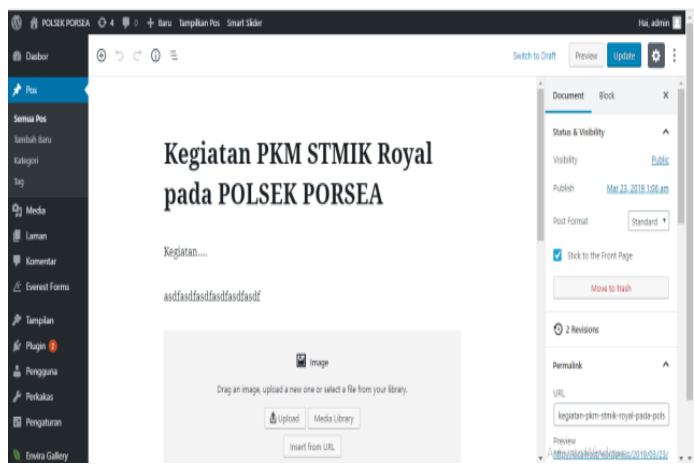

Gambar 2. Tampilan Halaman Admin Manajemen Website

Berikut adalah tampilan utama website yang akan diakses oleh public yang menyediakan informasi kegaitan polsek, prestasi kinerja, serta pelayanan yang diberikan oleh polsek Porsea

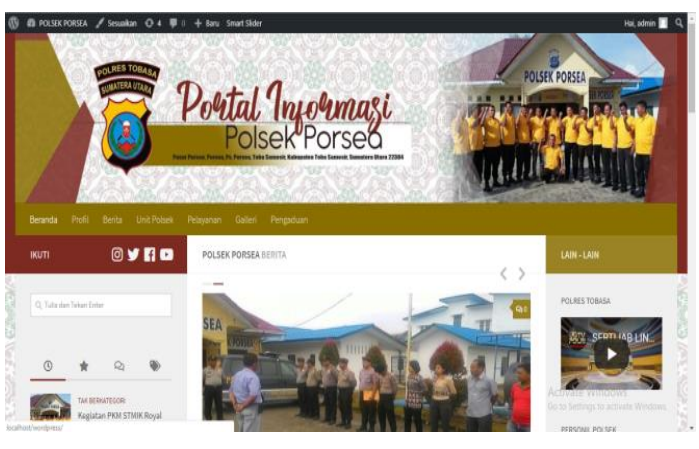

Gambar 3. Tampilan Halaman Website

Berdasarkan pemantauan yang dilakukan oleh tim pelaksana selama proses pelatihan, kemajuan yang dicapai oleh staf IT kepolisian Polsek Porsea yang mengikuti pelatihan memiliki kemajuan yang baik, diantaranya dari 
yang menggunakan komputer untuk pembuatan surat-surat saja, sekarang staf yang terlibat dapat menggunakan aplikasi komputer dalam proses berita, sistem informasi, berbagi informasi melalui media informasi website.

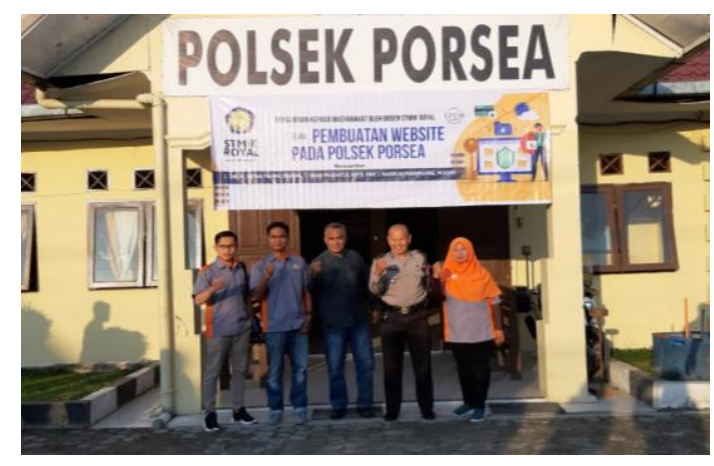

Gambar 4. Sambutan Hangat dari Kapolsek Porsea

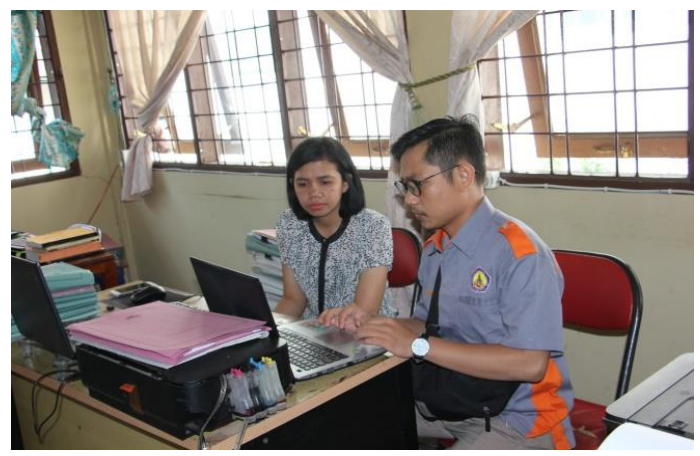

Gambar 5. Kegiatan Pelatihan kepada salah satu Staf IT Polsek Porsea

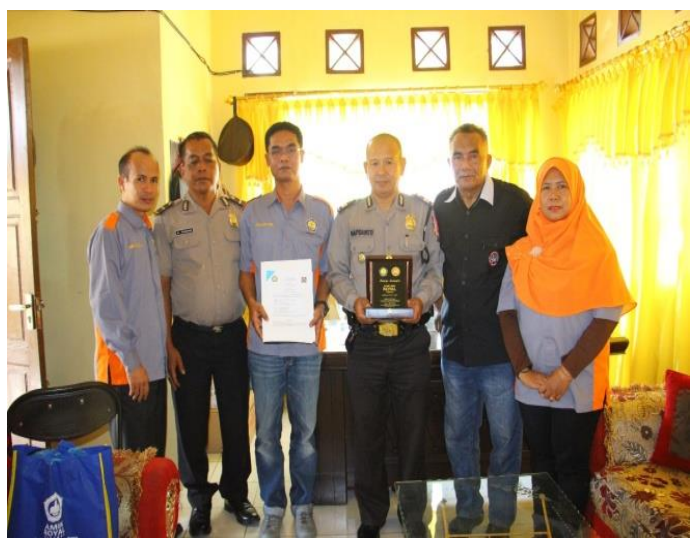

Gambar 6. Penyerahan Sertifikat dari STMIK Royal kepada Polsek Porsea

\section{SIMPULAN}

Berdasarkan kegiatan pengabdian yang telah dilakukan maka dapat disimpulkan bahwa Pelatihan ini sangat bermanfaat bagi staf kepolisian, terutama staf IT karena setelah dilaksanakan pelatihan selanjutnya mereka dapat menerapkan manajemen informasi, dan memberikan informasi dengan cepat dan tepat melalui media online atau media informasi website.

Hasil dari kegiatan PkM ini adalah pelatihan berjalan dengan baik, lancar dan mendapat respon yang sangat positif dari peserta, hal ini terlihat dari banyaknya pertanyaan-pertanyaan yang diajukan peserta kepada narasumber.

\section{DAFTAR PUSTAKA}

MMS, Victor, 2018. "Perancangan Website Sebagai Media Promosi Dan Penjualan Produk". Jurnal TAM (Technology Acceptance Model) Volume 9, Nomor 1, Juli 2018 Hal. 15-21

Utama, Yadi, 2011. "Sistem Informasi Berbasis Web Jurusan Sistem Informasi Fakultas Ilmu Komputer Universitas Sriwijaya". Jurnal Sistem Informasi (JSI), VOL. 3, NO. 2, Oktober 2011.

Mayangky, Nissa Almira dan Suharyanto. "Perancangan Sistem Informasi Sentra Pelayanan Kepolisian Terpadu pada Polsek Citeureup Cimahi”. Jurnal SISFOKOM, Volume 07, Nomor 01, Maret 2018. 